\title{
レーザー解説
}

\author{
超伝導空洞を用いた古典的メーザーの開発 \\ 加藤景三*・高橋邦治**・南 一 男 ${ }^{*} \cdot$ 粟野 満*** \\ (1991年10月25日 受理)
}

\section{Development of a Classical Maser Utilizing Superconducting Cavity}

\author{
Keizo KATO*, Kuniharu TAKAHASHI * ${ }^{*}$, Kazuo MINAMI* and Mitsuru AWANO***
}

(Received October 25, 1991)

\begin{abstract}
The studies on a high-power microwave pulse source utilizing a superconducting cavity are described. A great amount of RF energy can be stored in a superconducting cavity by a CW solid-state oscillator with small output. The stored energy can be released within a short time to an output circuit by a switching mechanism, resulting in a high-power microwave pulse which may not be available by usual $\mathrm{CW}$ solid-state oscillators. Microwave pulses are extracted from the cavity by using three different kinds of switches: a mechanical and a discharge switches and superconducting thin films.
\end{abstract}

Key Words: Classical maser, Superconducting cavity, Microwave pulse, Switching

\section{1.はじめに}

超伝導空洞はQ值が常伝導のものよりもはる かに大きく，非常に小さい入力で十分大きな電 磁エネルギーを蓄積できる。このエネルギーを Qスイッチングにより短時間に放出させれば, 他の方法では得にくい大出力のマイクロ波パル スを発生できる可能性がある。この様なマイク ロ波パルスは, 各種科学実験, ミリ波レーダー 等に独特の応用が期待される。この場合, RF 磁界による空洞の常伝導転移やRF絶縁破壊に よって蓄積できるエネルギーの限界が決まる。
従来の液体へリウムを用いた超伝導空洞は経済 的に高価であって，これを利用した本方式は科 学的興味の段階に止っていた。しかし，1986年 酸化物高温超伝導体の発見により液体窒素温度 $(77 \mathrm{~K})$ での超伝導空洞の利用の可能性が生れ た。現在まだ開発中ではあるが ${ }^{1)}$ 着実な進歩が 見られ，将来はこれを用いた本方式のミリ波パ ルス源の実用化が期待される。

本方式は古典的メーザーの一種と考えられ， 1976 年以来, 我々が提案してきたものであ

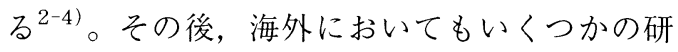
究が行われている。Birxらは, 空洞からエネル

$*$ 新潟大学工学部電気電子工学科 (下950-21 新潟市五十嵐2の町8050)

$* *$ 新潟大学大学院自然科学研究科 (T950-21 新潟市五十嵐20町8050)

$* * *$ 東京工科大学工学部機械制御工学科（１92 八王子市片倉町1404-1)

* Department of Electrical and Electronic Engineering, Niigata University (8050 Ikarashi 2-no-cho, Niigata 950-21)

$* *$ Graduate School of Science and Technology, Niigata University (8050 Ikarashi 2-no-cho, Niigata 950-21)

$* * *$ Department of Mechatronics, Tokyo Engineering University (1404-1 Katakura-cho, Hachiohji, Tokyo 192) 
ギーを放出させるための干涉型スイッチを提案

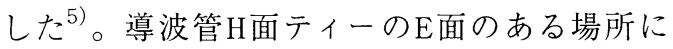
細い放電管を挿入したもので，放電プラズマの 発生により定在波の位置を $1 / 4$ 波長移動させて 外部に出力を取り出した。スイッチング後の空 洞の外部Q值を十分下げられないが，プラズマ 発生用の放電による雑音が出力回路に現れにく い長所がある。彼等はこれを用いて周波数 $9.2 \mathrm{GHz}$ の $\mathrm{TE}_{012}$ 円筒形鉛超伝導空洞からのマイ クロ波パルスの取り出しを行い, 最高 $10^{4}$ 倍の パルス利得を得た6)。Alvarezらは, TE 320 球形 鉛超伝導空洞と干涉型スイッチを用いて, 大出 カレベルのパルス抽出の実験を行った7)。パル ス出力 $150 \mathrm{~kW}$, 時間幅 $2 \mu \mathrm{s}$, 従ってパルス利 得 35 倍を達成した。また，長さ $1.2 \mathrm{~m}$ の加圧し たSバンド導波管を用いて常伝導空洞を作り, $\mathrm{SLAC}$ クイストロンからの入力 $7 \mathrm{MW}$, 時間幅 $2 \mu \mathrm{s}$ に対して, パルス出力 $158 \mathrm{MW}$, 時間幅 10nsを得た。Baraevらは，パルス取り出し技術 の高効率化に関する理論解析を行った ${ }^{8)}$ 。空洞 に最大のエネルギーを蓄積するには入力回路を 臨界結合にすればよいが，蓄積の初期には反射 が大きく無駄が多いので，効率をあげるにはむ しろ密結合にする方がよと述べている。 Artemenkoらは，常温のTE $0,1,25$ 円筒モード鉛 空洞を用いてパルス取り出しを行っている 共振周波数は2.8GHzで, 出力回路にはカット オフ導波管を用いた。スイッチングは空洞に挿 入した一対の電極間に大気中火花放電を行わ せ，電磁界のモード変換を起こさせる。パルス 電力利得 20 倍, 時間幅 $100 \mu \mathrm{s}$ の出力を得た。

我々は, 沉用のミリ波パルス源を目指した基 礎的研究を行っており, 以下に経過を紹介する。 ただし，使用周波数は $2.8 \mathrm{GHz}$ であり，ミリ波 については今後実験して行くつもりである。本 研究の装置は, 出来るだけQ值の高い超伝導空 洞とこれからエネルギーを取り出すマイクロ波 スイッチの二点からなっている。第一の空洞に ついては多くの研究者によって開発が進められ ているが，第二のスイッチについては研究例が 少ないので本研究の中心課題である。スイッチ
ングの方法としてはいくつかの方法が考えられ るが,ここでは現在までに試みている三種類の スイッチングについて述べる。

\section{2. パルス抽出の原理 $2-4)$}

空洞におけるエネルギーの蓄積と放出を考察 するため，等価回路による解析を行う。まず， 一開口空洞について共振状態にある電源によっ てエネルギーを蓄積した定常状態を考える。空 洞を集中定数の並列共振回路で表現し, 物理量 の間の対応づけを行うと空洞内のエネルギーU は次の様に表される。

$$
U=\frac{4 \beta_{1}}{\left(1+\beta_{1}\right)^{2}} \frac{Q_{U}}{\omega} P_{1}
$$

ここで, $\beta_{1}$ は入力結合定数で $\beta_{1}=Q_{\mathrm{U}} / Q_{\mathrm{E} 1}, Q_{\mathrm{U}}$ は無負荷 $Q$ 值, $Q_{\mathrm{E} 1}$ は入力側の外部 $Q$ 值, $\omega$ は共 振周波数， $P_{1}$ は入力電力である。上式より最大 のエネルギーが蓄積されるのは $\beta_{1}=10$ 場合で あることがわかる。この時, 反射電力 $P_{\mathrm{r}}$ は $P_{\mathrm{r}}=$ $P_{1}\left(1-\beta_{1}\right)^{2} /\left(1+\beta_{1}\right)^{2}=0$ となり, 臨界結合と呼 ばれる。

次に, パルスの取り出しを考察する。臨界結 合でエネルギーを蓄積して定常状態に達した 後, 出力結合係数 $\beta_{2}$ をできるだけ急速に0から 大きな值に近づける。この操作をスイッチング と呼ぶ。ここで, $\beta_{2}=Q_{\mathrm{U}} / Q_{\mathrm{E} 2}$ であり, $Q_{\mathrm{E} 2}$ は出 力回路に対する外部 $Q$ 值である。まず，理想的 な場合としてステップ状のスイッチングを考え る。二開口空洞についての過渡現象解析を行う と, 出力電力 $P_{2}(t)=\omega \mathrm{U}(t) / Q_{\mathrm{E} 2}(t)$ は $t=+0$ で 最大值 $P_{2}(+0)=4 \beta_{1} \beta_{2} P_{1} /\left(1+\beta_{1}\right)^{2}$ をとる。入 力側の結合度 $\beta_{1}$ を臨界結合 $\beta_{1}=1$ とするとき, $P_{2}(0) / P_{1}=\beta_{2}=Q_{\mathrm{U}} / Q_{\mathrm{E} 2}$ となる。すなわち，入 力の $\beta_{2}$ 倍の瞬時電力が出力側に現れる。ただ し空洞内のエネルギーをすべて取り出すには, 時定数 $\tau=\mathrm{Q}_{\mathrm{L}} / \omega$ 以上の時間を必要とする。ここ で, $Q_{\mathrm{L}}=Q_{\mathrm{U}} /\left(1+\beta_{1}+\beta_{2}\right)$ である。実際のスイッ チングでは， $\beta_{2}$ を増加させるために有限時間 を要する。そのため, パルス高は $\beta_{2}$ 倍よりも 小さくなることが予想される。この場合につい 
て， $\beta_{2}$ の変化をステップ状変化の重ね合せと 考え極限をとると, 空洞への入出力に関する微 分方程式が得られる。これより, 空洞内の工ネ ルギー $U(t)$ と出力電力 $\mathrm{P}_{2}(t)$ は次の様に求めら れる。

$$
\begin{aligned}
& U(t)=U_{0} f^{2}(t) \\
& P_{2}(t)=\frac{4 \beta_{1} \beta_{2}(t)}{\beta_{3}^{2}(0)} f^{2}(t) P_{1} \\
& \beta_{3}(t)=1+\beta_{1}+\beta_{2}(t) \\
& f(t)=\exp \left[-\frac{\omega}{2 Q_{\mathrm{U}}} \int_{0}^{t} \beta_{3}\left(t^{\prime}\right) \mathrm{d} t^{\prime}\right] \\
& \times\left[1+\frac{\omega \beta_{3}(0)}{2 Q_{\mathrm{U}}} \int_{0}^{t} \exp \left\{\frac{\omega}{2 Q_{\mathrm{U}}}\right.\right. \\
& \left.\left.\times \int_{0}^{t^{\prime}} \beta_{3}\left(t^{\prime \prime}\right) \mathrm{d} t^{\prime \prime}\right\} \mathrm{d} t^{\prime}\right]
\end{aligned}
$$

次に, 我々が提案したSマトリクスによるパ

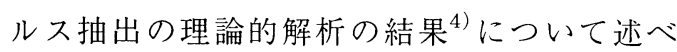
る。上記の等価回路による方法と結果が一致す る場合も多いが，本方法では空洞の具体的パラ メー夕を直接扱える利点がある。Fig.1の様に 一様な断面を持つ導波管をある距離を隔てて金 属板で仕切った2開口空洞の定常状態を考える。 いま，左の入力空に振幅 $a_{1}$ の入射波がある時, 短絡面1４に打いて矢印の方向に進む電磁波を 図の様に定義する。面 2 と 3 の間の距離 $l$ は $l=$ $\lambda_{\mathrm{g}} / 2$ である。ここで, $\lambda_{\mathrm{g}}$ は共振時の管内波長 である。入力空, 出力空の電界透過係数をそれ ぞれ $k, h$ と表す。電磁波が距離 $l$ を往復する間 の減衰量を $\exp (-\alpha)$ とする。 $\omega, k, h$ および $\alpha$

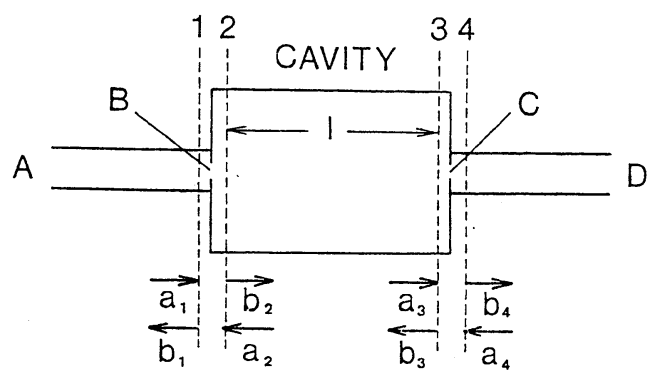

Fig.1 Two-port cavity.
によって空洞の電気的特性は完全に決まる。こ れらの定数は測定によって求めることができ る。空洞の $Q_{\mathrm{U}}$ が大きいことから， $\alpha \ll 1, k^{2} \ll 1$, $h^{2} \ll 1$ 近似を用いるとSマトリクスから次式が 得られる。

$$
\begin{aligned}
\frac{b_{1}}{a_{1}} & =-1+\frac{k^{2}}{\alpha+\left(k^{2}+h^{2}\right) / 2} \\
\frac{b_{2}}{a_{1}} & =\frac{\mathrm{j} k}{\alpha+\left(k^{2}+h^{2}\right) / 2} \\
\frac{b_{4}}{a_{1}} & =\frac{-h k}{\alpha+\left(k^{2}+h^{2}\right) / 2}
\end{aligned}
$$

まず，エネルギーを空洞に蓄積する場合には 出力透過係数 $h$ を $h=0$ とする。 $\mathrm{d}\left|b_{2} / a_{1}\right| / \mathrm{d} k=0$ と置くと $\alpha=k^{2} / 2$ となる。これを臨界結合と呼 び, この時最大のエネルギーが蓄積される。次 に, 空洞からパルスを取り出す過程について考 える。臨界結合状態でエネルギーを供給した後,

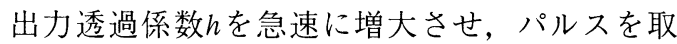
り出す。そのために, 空洞の過渡現象について 考える。Fig.1において，明らかに $a_{2}(t)=-(1$ $\left.-h^{2}\right)^{1 / 2} \exp (-\alpha) b_{2}\left(t-t_{0}\right)$ が成立する。ここで, $t_{0}$ はエネルギーが空洞を一往復する時間であっ

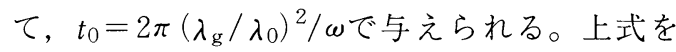
級数展開すると次の微分方程式が得られる。

$$
\begin{aligned}
& \frac{\mathrm{d} b_{2}}{\mathrm{~d} t}+\frac{b_{2}}{2 \tau}=\mathrm{j} \frac{k}{t_{0}} a_{1} \\
& \tau=\frac{t_{0} / 2}{\alpha+\left(k^{2}+h^{2}\right) / 2}
\end{aligned}
$$

ここで, $\tau$ は空洞の時定数で時間的に変化する 出力透過係数 $\mathrm{h}$ 関数である。簡単のため, $h$ を時刻 $t=0$ で0からh(>0)にステップ状に増大 させた場合について考える。(4)式を解くと， 出力が最大になるのは $t=0$ の時であり, パルス

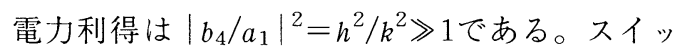
チング前後の空洞の時定数をそれぞれ $\tau^{\prime} ， \tau^{\prime \prime}$ と すると， $\tau^{\prime}=t_{0} /\left(2 k^{2}\right), \quad \tau^{\prime \prime}=t_{0} /\left(2 k^{2}+h^{2}\right)$ である ので, パルス電力利得として次式が得られる。

$$
\left|\frac{b_{4}}{a_{1}}\right|^{2}=\frac{h^{2}}{k^{2}}=2\left(\frac{\tau^{\prime}}{\tau^{\prime \prime}}-1\right) \sim \frac{2 \tau^{\prime}}{\tau^{\prime \prime}}
$$




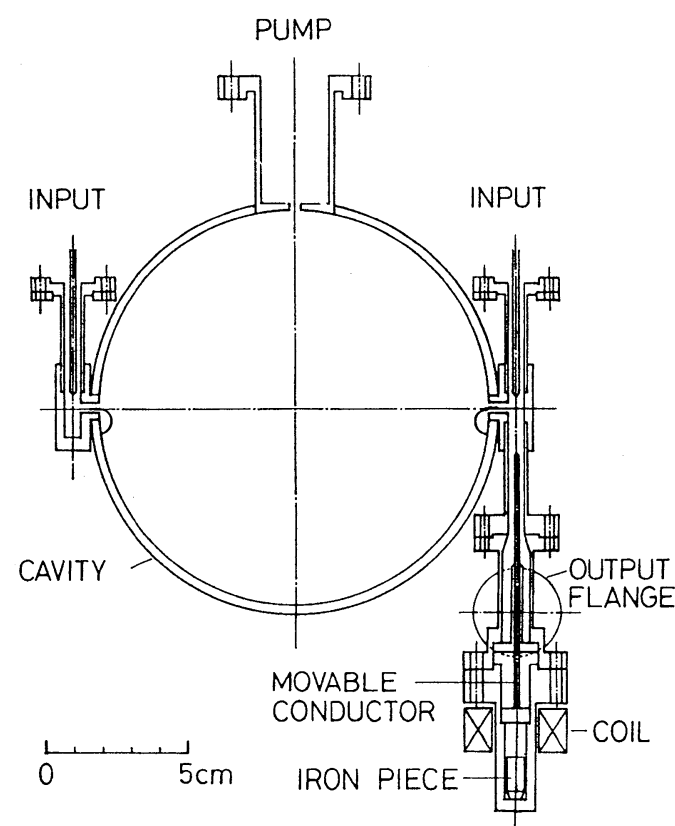

Fig. 2 Cross section of a $\mathrm{TE}_{011}$ mode cylindrical cavity with a mechanical switch

すなわち, 出力パルス電力の最大值はスイッチ ング前後の時定数の比の約 2 倍となる。

\section{3. 機械的スイッチによるパルス抽出 ${ }^{10-12)}$}

Fig.2は，出力回路部に機械的スイッチを持 つマイクロ波空洞の断面図である。空洞として は内部 $Q$ 值が理論的に大きくなる円筒 $\mathrm{TE}_{011}$ モードを採用し，共振周波数の設計值を $2.85 \mathrm{GHz}$ に選んだ。理論的な $Q_{\mathrm{U}}$ は円筒の直径 と長さが等しい時に最大となるので，この長さ を $13.85 \mathrm{~cm}$ とし。空洞の材料は無酸素銅で, その内面にホウフッ化鉛による電気めっきを 行った。上方に伸びた左右の一対の円筒には, クライオスタット上部から導かれている同軸 ケーブルが入るようになっており，それぞれマ イクロ波入力用，透過出力測定用に使われる。 同軸ケーブルと空洞の結合のため，空洞には直 径4 mmの結合空があけてあり，磁界結合を強く するために銅線でループを設けた。右下方にあ る出力回路はカットオフ導波管となっており, 中心導体となる直径 $2 \mathrm{~mm}$ のステンレス棒を距離

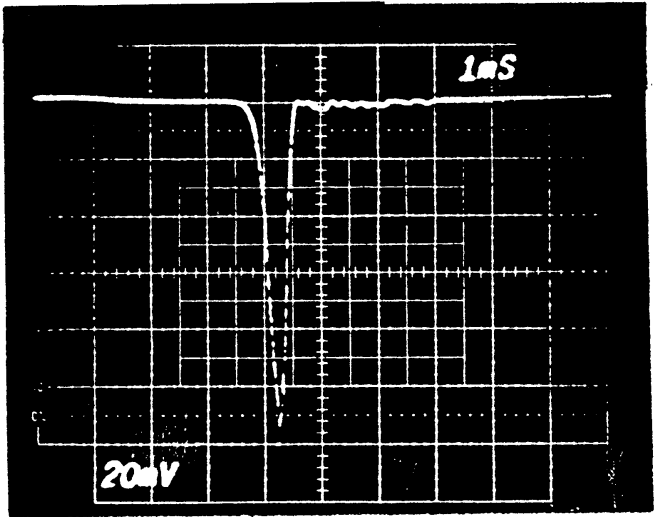

Fig.3 An example of the output pulses.

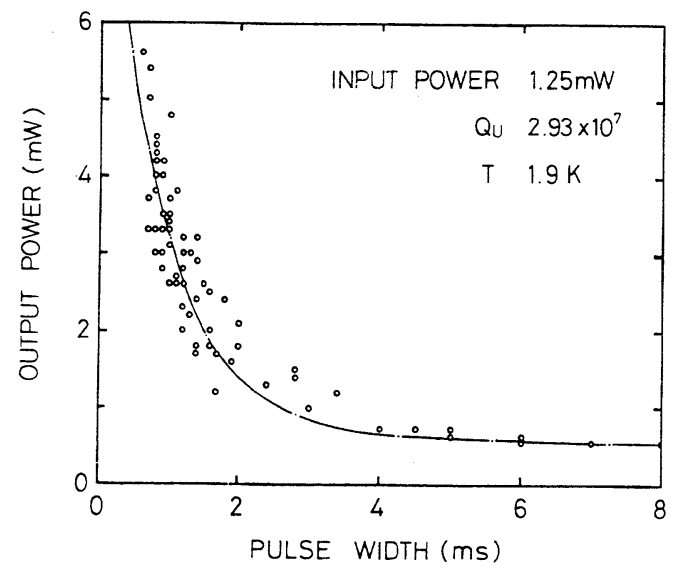

Fig.4 Relationship between peak output powers and the pulse time width for an incident power of $1.25 \mathrm{~mW}$.

$10 \mathrm{~mm}$ 急激に打ち上げると, 結合空の入口まで 達するようになり同軸導波管に変る。これによ り結合度が急激に変化し，パルス出力が得られ る。ステンレス棒の打ち上げは，コイル(直径 $0.4 \mathrm{~mm}$ 銅線，巻数500)に衝撃電流を流し，ステ ンレス棒の下方にある鉄片を急激に打ち上げて ステンレス棒の下部に衝突させることによって 行う。 $4.2 \mathrm{~K}$ に冷却した時のこの空洞の共振周 波数は $2.87 \mathrm{GHz}$, 無負荷 $Q$ 值は $Q_{\mathrm{U}}=1.67 \times 10^{7}$ であり， $Q_{\mathrm{U}}$ は常温の銅空洞の約 $10^{3}$ 倍になった。 また， $1.9 \mathrm{~K}$ まで冷却すると $Q_{\mathrm{U}}=2.93 \times 10^{7}$ と なった。 


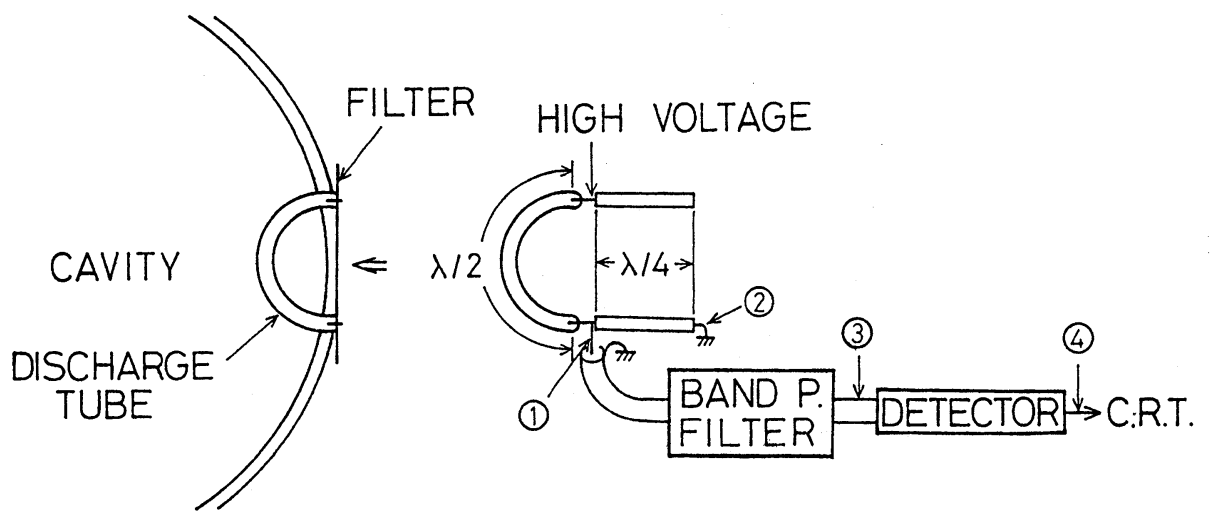

Fig. 5 Output circuit of a gas discharge switch.

Fig.3は，温度1.9Kの場合に得られたパルス 出力波形の一例である。Fig.4には，1.9Kにお いて得られたパルス電力のピーク值とパルス時 間幅をプロットした。ここでパルス幅は半值幅 の2倍をとっている。1.9Kでのピーク值は， $4.2 \mathrm{~K}$ の場合よりもやや大きい。なお, 空洞入 口に拈ける入射電力は $1.25 \mathrm{~mW}$ あ゙あので，パ ルス電力利得は最大 5 倍程度である。この結果 は, スイッチング時間が空洞の時定数てに比べ て十分小さくないことを示している。スイッチ ング時間を短くするために, 出力回路のステン レス棒の打ち上げ方法を色々と工夫したが, 機 械的方法による限り $1 \mathrm{~ms}$ 程度の打ち上げ速度が 限界であった。

\section{4. 放電スイッチによるパルス抽出 ${ }^{13)}$}

空洞のある $Q_{U}$ すなわちある時定数てに対して パルス電力利得を大きくするためには，スイッ チング時間を短くする必要がある。一つの可能 性として, 放電スイッチングによるパルス取り 出しの実験を行った。

使用した円筒空洞はFig.2と同じである。入 力結合部はFig.2と同じであるが, 出力結合部 はFig.5の様である。気体放電は立上がり時間 を数ns程度にすることも可能で, 出来たプラズ マにより出力アンテナを形成すれば, 高速に金 属アンテナを空洞に挿入したことと等価にな る。しかし，放電のために数 $\mathrm{kV}$ 以上の高電圧
を使用し，放電電流も数 $10 \mathrm{~A}$ 以上であるため, マイクロ波出力回路に対しては放電ノイズが重 大な悪影響を与える。マイクロ波検出器には数 Vまでしか印加できず，アンテナ用放電管に高 電圧給電線を単純に接続することはできない。 そこで, Fig.5に示した様な放電ノイズを阻止 する回路を考案した。すなわち，ガラスエポキ シ基板上にマイクロストリップ線路を構成し た。放電管の高電圧側電極には $1 / 4$ 波長オープ ンスタブが接続されており, 直流的には浮いて いるが, マイクロ波に対してはアースと等価で ある。従って，ここに高電圧を印加してもマイ クロ波に対して悪影響を与えない。一方，放電 管のアース側電極には1/4波長ショートスタブ が接続されている。放電電流はアースへ流れ込 むが, マイクロ波はアースに対してはインピー ダンスが $50 \Omega$ よも十分大きくなり出力回路へ 取り出される。信号は帯域フィルターを通し検 出器で観測する。放電管はパイレックス製の半 円形のもので, 大半径 $12.5 \mathrm{~mm}$, 小半径 $10.5 \mathrm{~mm}$, 内径 $2 \mathrm{~mm}$ である。両端に太さ $1 \mathrm{~mm}$ の金属電極を 設け, 常温で50 Torrのヘリウムガスを封入し た。電極に印加するパルス電圧は, $2 \mathrm{nF}$ のコン デンサ放電により発生させた。充電電圧が $10 \mathrm{kV}$ の時, 放電電流 $168 \mathrm{~A}$, 時間幅400nsであり, 常温と低温で特に変化は見られなかった。エネ ルギー蓄積時間中に放電管が存在しても，出力 透過係数 $\mathrm{h}$ 零になるように電極の寸法や位 


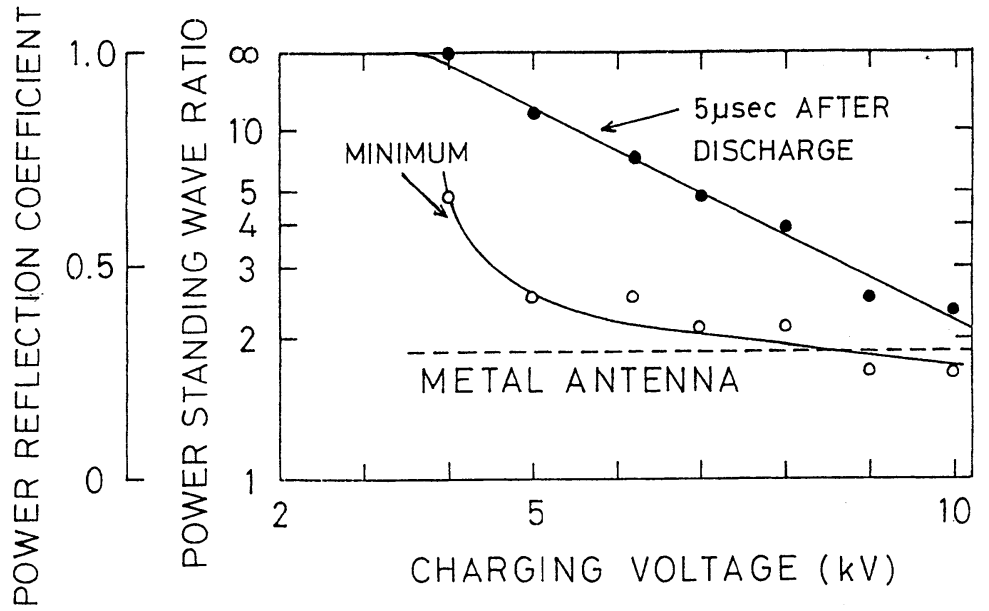

Fig. 6 Power standing wave ratio of a discharge antenna or power reflection coefficient vs charging voltage.

置，空洞の穴の形状には工夫を要した。放電時 に出力回路の各部に誘起される雑音電圧を測定 した。充電電圧は $10 \mathrm{kV}$ とた。Fig.5の(1), (2) の点ではアース電位にあるが，放電により約 20Vのノイズ電圧が見られた。しかし, 带域フィ ルタを通した後の(3)，(4)の点では $1 \mathrm{~V}$ 程度に低 下し, 検出器を破壊しない限度内に抑制できた。

アンテナとしての動作を確認する方法とし て, 出力回路から逆にマイクロ波を送り込み, その反射波を観測した。プラズマが無いとき， 1/4ショートスタブがあるだけなのでここで全 反射が起こる。プラズマが出来ると，アンテナ からマイクロ波が放射され，反射波が減少する。 Fig.6に結果をまとめた。横軸はコンデンサの 充電電圧であり，アンテナ中に作られるプラズ マの密度の初期值にほぼ比例する。充電電圧を 変化させて, 反射信号の最小值 $(\bigcirc)$ と放電後 5 $\mu \mathrm{s}$ 後の反射信号 $(\mathbf{O})$ を電力定在波比 (PSWR) で示した。ここで, PSWRは電力反射係数をR とすると $(1+R) /(1-R)$ で与えられる。点線は 放電管を同じ形状の金属アンテナで置き換えた ときのPSWRである。充電電圧の上昇と共に放 電アンテナのPSWRは減少し, 特性が向上する。 $6 \mathrm{kV}$ 以上では○はほぼ金属アンテナと等しく なっている。また，充電電圧の上昇と共にアン テナとして動作する時間も長くなっている。

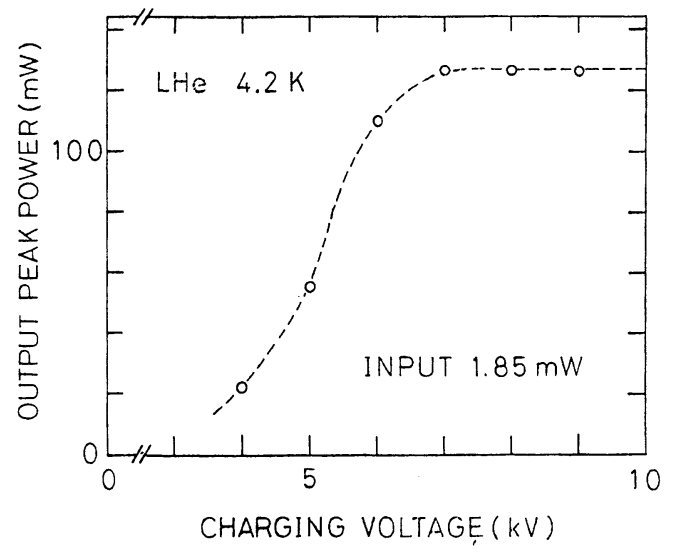

Fig.7 Peak output power at $4.2 \mathrm{~K}$ vs discharging voltage. The input power is $1.85 \mathrm{~mW}$.

次に, 超伝導空洞からのパルス取り出しの結 果を述べる。まず, 温度 $4.2 \mathrm{~K}$ の時の鉛超伝導 空洞の定数を測定した。共振周波数は $2.868 \mathrm{GHz}$ で, $Q_{\mathrm{U}}=3.4 \times 10^{6}, \tau=93 \mu \mathrm{s}, \beta_{1}=$ $1, \beta_{2}=0$ と求められた。 $Q_{U}$ は常温のときの約 200 倍となっている。この空洞に入力電力 $1.85 \mathrm{~mW}$ 入射させてエネルギーを蓄積した 後，パルスを取り出した。Fig.7は得られた出 カパルスのピーク值を充電電圧に対してプロッ トしたものである。充電電圧が $7 \mathrm{kV}$ 以下では出 力が低下している。7 $\mathrm{kV}$ 以上では, 出力は 


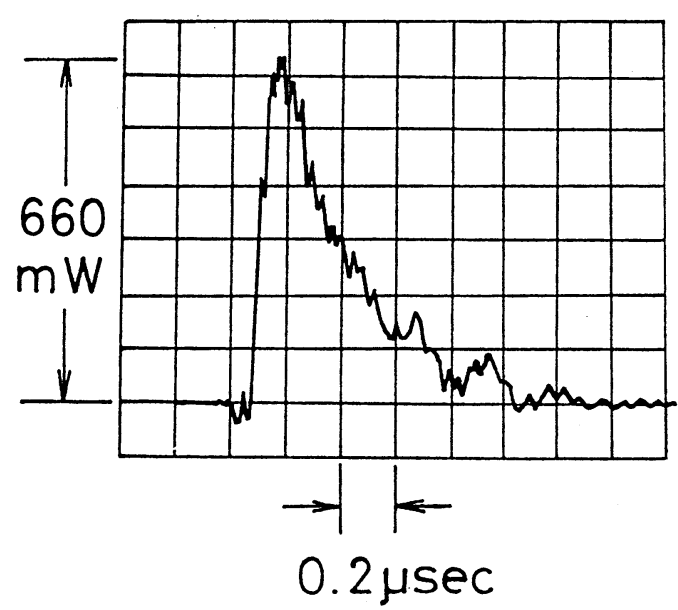

Fig. 8 Waveform of an output pulse signal at $3.0 \mathrm{~K}$. The time sweep is $0.2 \mu \mathrm{s} / \mathrm{div}$.

$130 \mathrm{~mW}$ で飽和し，パルス電力利得は約 70 倍と なっている。

最も大きな利得が得られた場合の出力パルス 波形をFig.8に示す。空洞温度を減圧冷却によ

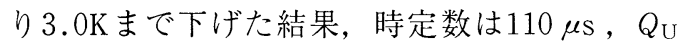
$=3.8 \times 10^{6}$ となった。充電電圧は $8 \mathrm{kV}$ であ。 空洞への連続入力 $1.85 \mathrm{~mW}$ に対して $660 \mathrm{~mW}$ ピーク出力が得られ, 利得は350倍に達してい る。波形から時定数を求めると, $\tau^{\prime \prime}=175 \mathrm{~ns}$ ある。スイッチング前の時定数が $\tau^{\prime}=110 \mu \mathrm{s}$ で あるので，(5)式より期待される電力利得は約 1,300 倍となる。実験ではこの $1 / 4$ 程度の出力し か得られていない。その主な理由として，(5) 式ではステップ状の出力結合係数の変化を仮定 したが，実験では有限なスイッチング時間を要 していることが考えられる。また，プラズマ表 面でマイクロ波の損失が起こっている可能性も ある。(5)式からわかるように，パルス電力利 得は内部 $Q$ 值 $Q_{\mathrm{U}}$ に比例する。本実験に扮ける $Q_{\mathrm{U}}=3.8 \times 10^{6}$ はあまり良好な值と言えない。 例えば，前節では $Q_{U}=2.9 \times 10^{7}$ が得られてい る。本実験では，スイッチング用放電管が存在 するが，それを除いてもほとんどQU一゙変化し なかったので, 低下の原因はめっき処理が不完 全であったこと, 到達真空度が不十分であった ためと思われる。文献によれば，我々と同じ鉛
超伝導空洞で $Q_{\mathrm{U}}=8.3 \times 10^{9}$ を達成している例 があるが ${ }^{14)}$ ，もしこの空洞で放電スイッチン グを行ったと仮定すると， $8 \times 10^{5}$ のパルス電力 利得が得られると想像される。しかし，この様 な高い $Q_{U}$ の空洞の実用性は未知数である。

\section{5. 超伝導薄膜スイッチによるパルス 抽出 ${ }^{15-17)}$}

高速スイッチングの別の可能性として，我々 は現在, 超伝導薄膜を用いる方法を試みている のでその概略を紹介する。

超伝導状態では，電磁波の侵入長はLondon の侵入長 $\lambda_{\mathrm{L}}$ で決まり，常伝導状態では古典的 表皮厚さ $\delta$ で決まる。ミリ波, マイクロ波につ

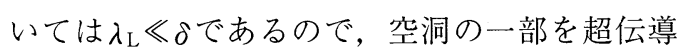
薄膜で構成し，これを高速に常伝導化すること により空洞内に閉じ达められたエネルギーをパ ルス的に取り出すことが可能である。ところで, (4) 式中の出力側の電界透過係数の時間の関数 $h(t)$ がわかれば出力波形が計算され，空洞への 入力に対する出力利得がわかる。ここで, 出力 側 (薄膜)の電界透過係数 $h$ は次式で与えられ $3^{16)}$ 。

$$
\begin{aligned}
h= & 4 \mid k_{1} k_{0}\left[\left(k_{1}+k_{0}\right)^{2} \exp \left(-\mathrm{j} k_{1} L\right)\right. \\
& \left.-\left(k_{1}-k_{0}\right)^{2} \exp \left(\mathrm{j} k_{1} L\right)\right]^{-1} \mid
\end{aligned}
$$

ただし， $k_{1}$ と $k_{0}$ はそれぞれ薄膜と真空における 波数で, Lは膜厚である。常伝導状態抢よび超 伝導状態の電界透過係数hは, 上式に扔いてそ れぞれ $k_{1}=(1+\mathrm{j}) / \delta, k_{1}=\mathrm{j} / \lambda_{L}$ と置くことによ り与えられ，スイッチング特性を解析すること ができる ${ }^{16)}$ 。

酸化物高温超伝導体が発見される以前に我々 は, $\mathrm{BaPb}_{1-x} \mathrm{Bi}_{x} \mathrm{O}_{3}(\mathrm{BPB})$ 超伝導薄膜を用いて実 験を行っている ${ }^{15)}$ 。スイッチングは, 臨界電 流密度を越えるような電流パルスを印加する方 法により超伝導状態から常伝導状態に転移させ て行った。その結果, パルス抽出が可能なこと が実験的に示された。現在は, 酸化物高温超伝 導体の一つである $\mathrm{Y}-\mathrm{Ba}-\mathrm{Cu}-\mathrm{O}(\mathrm{YBCO})$ 薄膜を用 いたスイッチング実験を試みているので，それ 


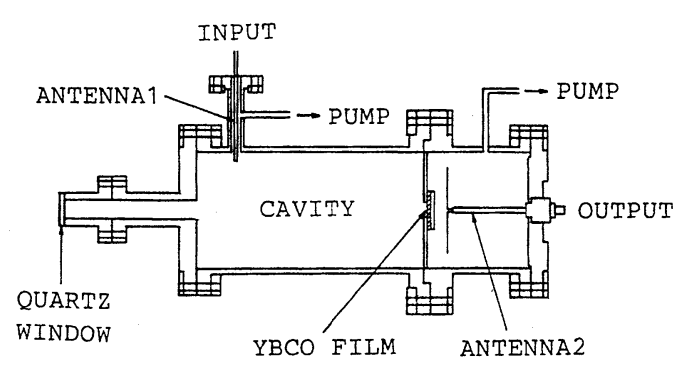

Fig.9 Cross section of a $\mathrm{TE}_{111}$ mode cylindrical cavity with a superconducting thin film switch.

について述べる。なお,スイッチングはレーザー 光パルスをYBCO超伝導薄膜に照射することに より行った。使用したYBCO超伝導薄膜は,レー ザーアブレーション法 ${ }^{18)}$ により作製した。波 長 $248 \mathrm{~nm}$ の $\mathrm{KrF}$ エキシマレーザーを使用し, $\mathrm{YBa}_{2} \mathrm{Cu}_{3} \mathrm{O}_{x}$ 焼結体をターゲットとし， $0.5 \mathrm{~mm} \times$ $8 \mathrm{~mm} \times 15 \mathrm{~mm}$ の $\mathrm{MgO}(100)$ 単結晶基板上に成膜 した。このYBCO薄膜のX線回折測定の結果で は，強いc軸配向した特性を示していた。ま た, 臨界温度 $T_{\mathrm{c}}$ は88.1Kで, 臨界電流密度 $J_{\mathrm{c}}$ は $1.2 \times 10^{6} \mathrm{~A} / \mathrm{cm}^{2}$ であった。な㧍，薄膜の厚さは $0.2 \mu \mathrm{m}$ である。

使用したマイクロ波空洞の断面図をFig.9に 示す。空洞は銅製で，直径 $67.5 \mathrm{~mm}$, 長さ $131 \mathrm{~mm}$ の TE 111 モード円筒空洞である。液体窒 素温度 $(77 \mathrm{~K})$ における共振周波数は, $2.84 \mathrm{GHz}$ である。YBCO薄膜は，空洞の右側の円盤中央 に設けた直径 $8 \mathrm{~mm}$ の出力空に装着し, 左側の石 英空より入射するレーザー光が直接当る様に なっている。ANTENNA 1は，マイクロ波入力 用のプローブアンテナで, 液体窒素温度付近で, 臨界結合になるように調節した。ANTENNA 2 は, 出力用のダイポールアンテナで, $\mathrm{YBCO}$ 薄 膜を透過したマイクロ波を検出する。空洞への マイクロ波供給は, $2.84 \mathrm{GHz}$ のCW 発振器を用 い, 約 $2.4 \mathrm{~mW}$ の電力が空洞に入力される。 YBCO薄膜の超伝導状態から常伝導状態へのス イッチングは，波長 $1.06 \mu \mathrm{m}$ ，時間幅 $10 \mathrm{~ns}$ のQ スイッチ Nd:YAGレーザーを用いた。出力パル ス信号の検出回路には，ミキサを用いた。すな

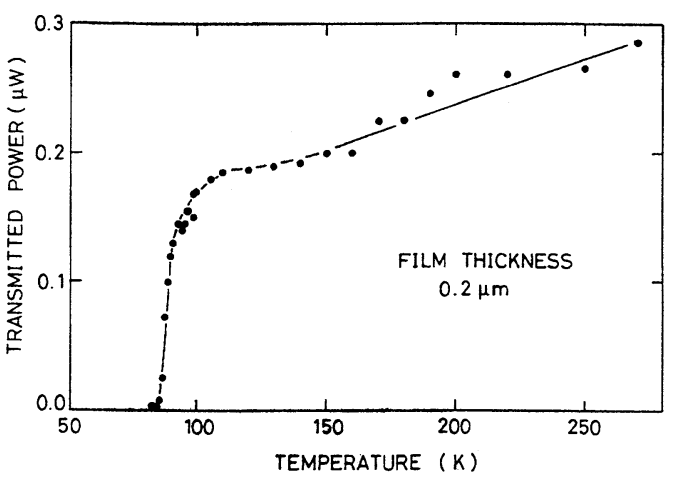

Fig.10 Temperature dependence of $\mathrm{CW}$ microwave transmission for a $0.2 \mu \mathrm{m}$ YBCO film. The diameter of the output window is $8 \mathrm{~mm}$.

わち周波数 $2.54 \mathrm{GHz}$, 電力 $26 \mathrm{~mW}$ の局部発振器 を用いて，出力パルス信号を約 $300 \mathrm{MHz}$ のビー

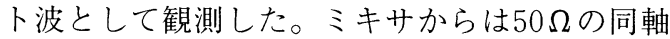
ケーブルでオシロスコープに接続し，同じく並 列接続した同軸ケーブルのインダクションノイ ズの差動をとり観測した。

Fig.10は，出力空にYBCO薄膜を装着した時 のマイクロ波透過電力の温度依存性である。透 過波は86K 程度以下では観測されず，86K以上 では急激に増加し，YBCO超伝導薄膜の $T_{\mathrm{c}}$ が $86 \mathrm{~K}$ であることがわかる。 $T_{\mathrm{c}}$ 以上では，透過電 力が温度と共に徐々に増加している。なお，透 過電力が空洞への入力電力約 $2.4 \mathrm{~mW}$ よもか なり小さい理由は, 出力空の面積 $(\mathrm{YBCO}$ 薄膜 の面積)が小さく，厚さ $0.5 \mathrm{~mm}$ の $\mathrm{MgO}$ 基板での 損失も含まれているからと考えられる。Fig.11 は，80KにおいてYBCO超伝導薄膜に $3.6 \mathrm{~mJ}$ の レーザー光を照射し，空洞からマイクロ波パル スの抽出をした結果の一例である。上部の信号 がレーザー光を照射した時の波形で，下部の信 号はレーザー光を遮断した時の波形すなわち， イズである。この時の空洞の $Q_{\mathrm{U}}$ は, 約 $4.4 \times$ $10^{4}$ であり，ほぼ臨界結合 $(\beta \sim 1)$ の状態である。 レーザー光がYBCO薄膜に照射されるまでは透 過波が現れておらず，レーザー光照射により約 $300 \mathrm{MHz}$ のビート波が観測されている。抽出さ れたマイクロ波パルスは, 破線で示したこの ビート波の包絡線に相当する。 


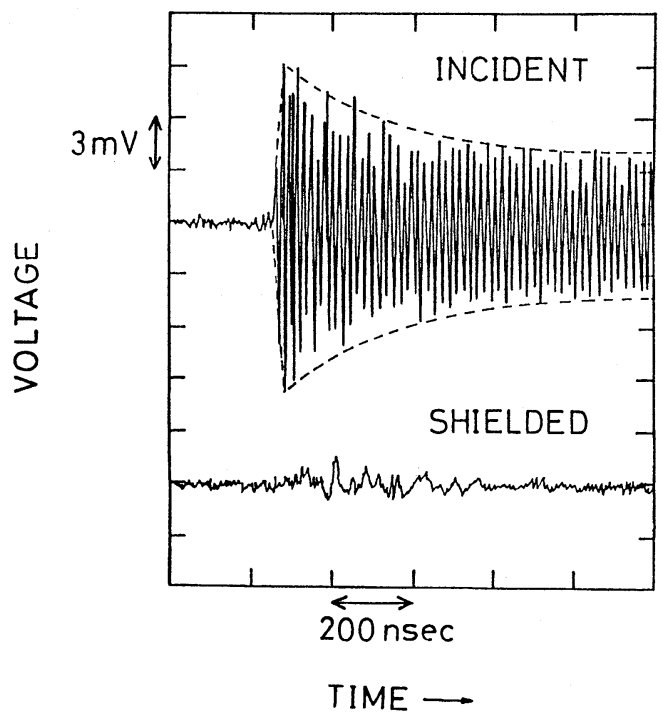

Fig.11 Typical example of microwave pulses from the cavity for a $0.2 \mu \mathrm{m}$ YBCO film measured by using a mixer. The laser energy is 3.6 $\mathrm{mJ}$.

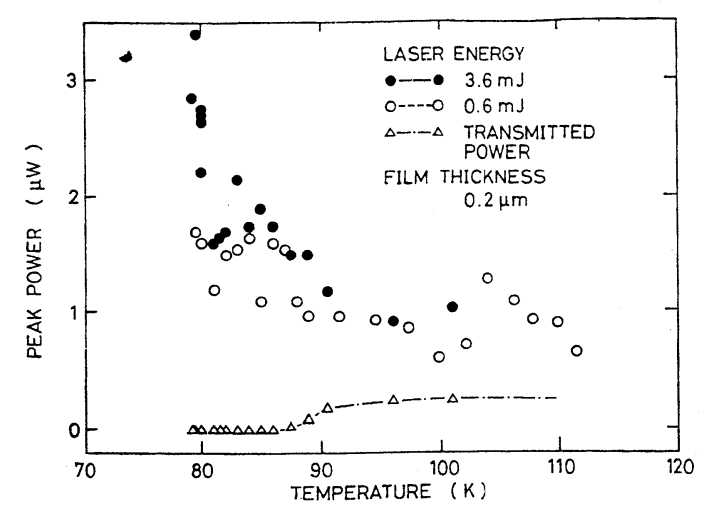

Fig.12 Temperature dependence of the peak power of output signals.

Fig.12は，レーザーエネルギーを変えて出力 パルスを測定した時のパルスのピーク值を測定 温度に対してプロットしたものである。86K以 上のデータは，レーザー照射前に観測される初 期のCW透過電力も含まれている。で示した デー夕はそれを示して扔り，Fig.10と同じもの である。出力パルスのピーク值は, 液体窒素温 度 $(77 \mathrm{~K})$ 付近で最大である。温度の上昇と共に,
ピーク值は減少している。しかし， $T_{\mathrm{c}}$ 以上で も定常時の透過電力レベル以上の出力パルスが 観測されている。また，レーザーエネルギーが 大きい方が得られる出力パルスが大きいことが わかる。Fig.12に示された結果は出力パルスが 数 $\mu \mathrm{W}$ であり, マイクロ波空洞への入力電力約 $2.4 \mathrm{~mW}$ の $10^{-3}$ 程度であり, 利得が非常に小さい。 これは，空洞の無負荷 $Q$ 值 $Q_{U}$ が低いことや $\mathrm{MgO}$ 基板での損失もあるが, 主に出力空の面積 (YBCO薄膜の面積) が小さいことにより出力側 の結合が弱いことが考えられる。また, 本実験 におけるYBCO超伝導薄膜のレーザー光パルス に対する応答速度は30ns程度であり，ボロメト

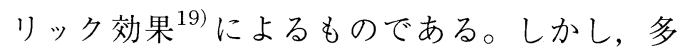
結晶薄膜を用いれば, 粒界 ACジョセフソン効 果に基づく高速応答が現れる可能性があり ${ }^{20)}$, さらに高速なスイッチングが可能と考えられ る。今後空洞全体を酸化物超伝導体にすること により，入力を上回る出力パルスを得る可能性 があると期待している。

\section{6. まとめ}

超伝導空洞とQスイッチを組み合わせた古典 的マイクロ波メーザーを試作し, 放電スイッチ により最大 350 倍のパルス電力利得が得られた。 本方式は，実用化への可能性があると考えられ るが，そのためにはまだいくつかの問題点が残 されている。

超伝導空洞としては, 酸化物超伝導体を用い て空洞を作製し，その特性を測定することが試 みられているが21-23), 液体窒素温度において まだ高い $Q$ 值は得られていない。現在，薄膜を 用いた $\mathrm{RF}$ 表面抵抗の測定では，液体窒素温度 において銅より2桁低くなっている1)。今後, 酸化物高温超伝導体で高いQ值の空洞が作製さ れれば，液体窒素温度で動作するパルス源が実 現できる可能性がある。スイッチングの方法と しては，放電スイッチが最大のパルス電力利得 が得られているが，ミリ波空洞に対しては電流 を大きくする必要がある。現在試みている超伝 導薄膜スイッチが将来有望であると考えてい 
る。

ここで紹介した実験では，周波数が $2.8 \mathrm{GHz}$ のSバンドマイクロ波を使用している。この周 波数帯では, 大電力マイクロ波パルス源として マグネトロンをはじめ安価な方法がある。従っ て, 本方式を実用化する意義があるのは周波数 $30 \mathrm{GHz}$ 以上のミリ波帯であると考える。大出力 ミリ波パルス源としては, サイクロトロン共鳴 メーザー, すなわちジャイロトロンが知られて いる ${ }^{24)}$ 。これは長パルス動作が可能で出力も 数百 $\mathrm{kWに}$ 達しているが, 高電圧電源や超伝導 磁場コイルを必要とし装置は非常に高価であ る。本方式は，パルス時間幅が $1 \mathrm{~ms}$ 以下であり, 本質的に短パルス動作しかできないが，ジャイ ロトロンよりも簡便で安価なパルス源として用 途があるのではないかと思われる。

本研究に関し, 高品質の YBCO超伝導薄膜を 作製して頂いた住友電気工業(株)大阪研究所永 田正之部長, 高野悟氏, 臀田典之氏に深く感謝 致します。

\section{参 考 文 献}

1）小中庸夫, 佐藤誠, 浅野秀文, 石井修: 応用 物理 60 (1991) 482 .

2) 南一男, 林泉: 核融合研究 36 (1976) 301.

3) K. Minami: Technical Report No.30, Institute of Plasma Physics, Nagoya University (1977) .

4) K. Minami and K. Hosoyama: Jpn. J. Appl. Phys. 18 (1979) 85.

5) D. L. Birx and D. J. Scalapino: IEEE Trans. Magn. MAG-15 (1979) 33.

6) D. Birx, G. J. Dick, W. A. Little, J. E. Mercereau and D. J. Scalapino: Appl. Phys. Lett. 33 (1978) 466.

7) R. A. Alvarez, D. Birx, D. Byrne, M. Mendonca and R. M. Johnson: IEEE Trans. Magn. MAG-17 (1981) 935.

8) S. V. Baraev and O. P. Korovin: Sov. Phys. Tech. Phys. 25 (1980) 1444.
9) S. N. Artemenko, V. L. Kaminskii and Y. G. Yushkov: Sov. Tech. Phys. Lett. 7 (1981) 656.

10) K. Minami: Jpn. J. Appl. Phys. 20 (1981) L407.

11）加藤景三, 小林修, 宮崎章, 南一男, 木村昭夫, 佐伯幸四郎, 粟野満, 大塚美枝子：核融合研 究 49 (1983) 13.

12）南一男, 佐伯幸四郎, 小林修, 大塚美枝子, 粟野満：電気学会論文誌 104-A (1984) 97.

13) O. Kobayashi, K. Minami, K. Saeki and M. Awano: J. Appl. Phys. 57 (1985) 105.

14) Y. Bruynseraede, D. Grole, D. Leroy and D. Morignot: Physica 54 (1971) 137.

15) K. Minami, K. Saeki, H. Kubo, M. Ohtsuka, M. Awano and H. Takai: J. Appl. Phys. 62 (1987) 1902.

16）高橋邦治, 加藤景三, 南一男: 電気学会論文 誌 110-A (1990) 402.

17) K. Takahashi, K. Minami, K. Kato, N. Yoshida, S. Takano and M. Awano: Jpn. J. Appl. Phys. Vol.31, No.1 (1992) 揭載予定.

18) N. Yoshida, M. Kubota, S. Takano, K. Sato, H. Hitotsuyanagi, M. Kawashima, T. Hara, K. Okaniwa and T. Yamamoto: Proc. 2nd Int. Symp. on Superconductivity (ISS '89), Tsukuba, Japan (1989) p.853.

19) K. Kato, K. Takahashi, K. Minami, N. Hayashi, S. Okuda, S. Takano, M. Ohtsuka and M. Awano: Jpn. J. Appl. Phys. 30 (1991) 258.

20) Y. Enomoto and T. Murakami : J. Appl. Phys. 59 (1986) 3807.

21) C. Zahopoulos, W. L. Kennedy and S. Shridhar: Appl. Phys. Lett. 52 (1988) 20.

22) E. Minehara, R. Nagai and M. Takeuchi : Jpn. J. Appl. Phys. 28 (1989) L100.

23) K. Kato, K. Takahashi, S. Yamakawa, K. Kumakura, M. Yamazaki, H. Mitera, K. Minami and M. Awano: Proc. 4th Workshop on RF Superconductivity, Tsukuba, Japan (1989) p.715.

24）南一男：レーザー研究 6 (1979) 352. 